\title{
Identification of Bryophytes in Jumog Waterfall, Karanganyar, Central Java, Indonesia
}

\author{
Yasir Sidiq1, Alanindra Saputra², Siti Kartika Sari \\ ${ }^{1}$ Universitas Muhammadiyah Surakarta, Surakarta, Indonesia \\ *yasir.sidiq@ums.ac.id
}

\begin{abstract}
Indonesia, as a mega-biodiversity country, has a high diversity of bryophytes (Liverworts, Hornworts, and Mosses). In addition, waterfall is one of the most optimum habitat for bryophytes. One of many waterfalls in Indonesia is Jumog Waterfall that is located in Karanganyar Regency, Central Java. This study aimed to identify bryophytes in Jumog Waterfall and analyze the genetic relationship among the species based on morphological characters. Explorative method was used to collect the samples. Identification of species was done by comparing morfological characters of the samples to handbook of identification. The results were; (1) there were fifteen species that found in Jumog Waterfall; (2) The highest similarity among species was 90\%. They were grouped into genus Fissidentales, Order Dicranales, and Order Hypnobryales. Meanwhile, the lowest similarity was 30.8\%. They were between Funaria hygrometrica and Riccia fliutans. It distinguished liverwort, hornwort, and mosses
\end{abstract}

Keywords: Bryophytes, Diversity, Genetic Relationship

\section{INTRODUCTION}

Indonesia is a tropical country. It is closed by rain forest with high rainfall. High humidity of rain forest is one of optimum condition of bryophytes to life. Therefore, it has high diversity of nonvascular plant, especially bryophytes (Aryanti and Gradstein, 2007). Instead of lichens, bryophytes play important role for water storage. For example, mosses in rain forest of Costa Rika storage around $406 \%$ of their dry weight at the end of rainy season (Hölscher et al., 2004). Another example for roles of Bryophyte in rain forest is in Sesaot Forest, Lombok, West Nusa Tenggara. There are two species that commonly have function as a pioneer on trunks of tree, namely floribundaria and vesicularia. Moreover, Bryophyte also has function as one of bioindicator for air pollution (Bawaihaty et al., 2014). Then, that is interested to know diversity of bryophyte in tropical area.

At less there are two factors that are needed for Bryophyte to grow, they are humidity and temperature. Temperature is influenced by elevation of the location. 
According (Bawaihaty et al., 2014), when elevation raised around $100 \mathrm{~m}$, temperature will fall $0.4^{\circ} \mathrm{C}$ until $0.7^{\circ} \mathrm{C}$. Lower temperature prevents the loss of water. In addition, high humidity condition provides more water for Bryophyte. Therefore, they thrive in a place with high humidity such as waterfall.

Waterfall is one of optimum place for bryophytes to life in tropical area. Many conifers, lichens, and bryophytes live there. Jumog is one of waterfall located in Mount Lawu, Central Java, Indonesia. Lawu is Rain Mount that consists of many locations of forest and Jumog is one of its wellsprings. According to temperature and humidity in Jumog waterfall were $24.8^{\circ} \mathrm{C}-30.6^{\circ} \mathrm{C}$ and $66 \%$ $82 \%$ respectively. There is no report about Bryophyte in that area. Therefore, identification is necessary.

There are three major groups of bryophyte, they are mosses, liverworts, and hornworts (Goffinet and Shaw, 2009). Many species of Bryophytes have successfully

identified in the worldwide. It is followed the data from there are 3000 species of Bryophyte and 1500 of them are found in Indonesia

(Bawaihaty et al., 2014). Recently, diversity in part of Mount Lawu, hiking track of Cemoro Sewu, has been reported. There are 85 species of bryophytes has been identified (Romawati et al., 2013). However, up to present, there is still no clear data related to bryophyte in Jumog.
This research was conducted in Jumog Waterfall which is located in Berjo Village, Karanganyar Region, Central Java (Dodik, 2011). Geographic location of Jumog Waterfall is 7037'52.11"S and 111007'36.77" E with elevation 3307ft (Anonimous, 2015). The data were collected on December 2015. Method of this research was exploration with purposive sampling (Musyarofah et al., 2015). Bryophyte specimens collected from stone and soil substrate that have high humidity. Then, specimens were identified by comparing to related research and handbook of Guide to the Liverworts and Hornworts of Java (Gradstein et al., 2011). The exploration was limited only in the riverside that connected to the waterfall. Sampling areas were $100 \mathrm{~m}$ along the river from waterfall. There were 10 areas of sampling (Figure 1).

Similarities among specimens were analyzed manually by comparing the morphological characters each other. Then, the dendogram was constructed by following this formula :

$$
S \stackrel{2 C}{A B}^{x 100 \%}
$$

Notes:

$\mathrm{S}=$ Similarity index

$\mathrm{A}=$ Total of characters of species $\mathrm{A}$

$B=$ Total of characters of species $B$

$\mathrm{C}=$ Total of similar characters of both species $A$ and $B$

\section{METHOD}




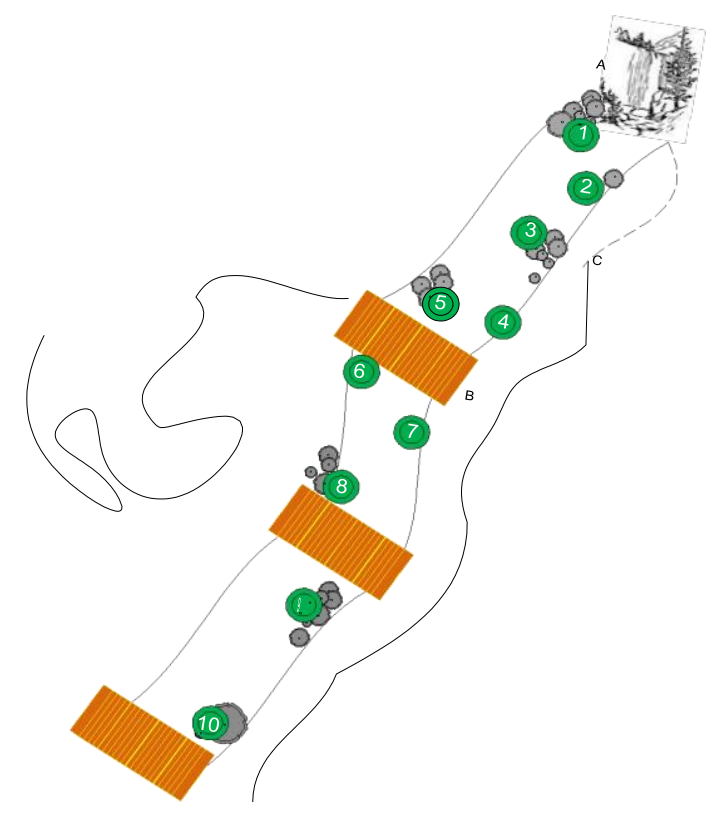

Figure 1. Map of sampling, Waterfall (A), Bridge (B), Stairs (C), sampling area (1-10)

\section{RESULTS AND DISCUSSION}

There were fifteen species of bryophytes collected and consisted of nine orders. The substrate was on stone and soil (Table 1). In addition, the similarity among them is displayed in Figure 2. This similarity based on morphological characters of gametophyte form of bryophyte.

Table 1. List of Species that found in along of the riverside of Jumog Waterfall

\begin{tabular}{|c|c|c|c|c|c|}
\hline No. & Classis & Order & Family & Species & Substrate \\
\hline 1 & Hepaticae & Metzgeriales & Metzgeriaceae & Metzgeria pubescens & Stones \\
\hline 2 & & Marchantiales & Marchanticeae & Marchantia polymorpha $L$. & Soil \\
\hline 3 & & Marchantiales & Ricciaceae & Riccia fluitans $L$. & Soil \\
\hline 4 & & Jungermanniales & Plagiochilaceae & Plagiochila asplenoides & Stone \\
\hline 5 & Anthocerotae & Anthocerotales & Anthocerotaceae & Phaeoceros laveis & Stone \\
\hline 6 & Musci & Dicranales & Dicranaceae & Dicranum japonicum & Stone \\
\hline 7 & & Dicranales & Mniaceae & Plagiomnium ciliare & Soil \\
\hline 8 & & Dicranales & Bartramiaceae & Bartramia laevisphaera & Stone \\
\hline 9 & & Hypnobryales & Pterobryaceae & Calyptothecium wightii & Stone \\
\hline 10 & & Hypnobryales & Lembophyllaceae & Camptochaete arbuscula & Stone \\
\hline 11 & & Fissidentales & Fissidentaceae & Fissidens fontanus & Stone \\
\hline 12 & & Fissidentales & Fissidentaceae & Fissidens javanicus & $\begin{array}{l}\text { Stone } \\
\text { Stone }\end{array}$ \\
\hline 13 & & Fissidentales & Fissidentaceae & Fissidens nobilis & Stone \& Soil \\
\hline 14 & & Bryales & Bryaceae & Rhodobryum ontariense & Stone \\
\hline 15 & & Funariales & Funariaceae & Funaria hygrometrica & \\
\hline
\end{tabular}




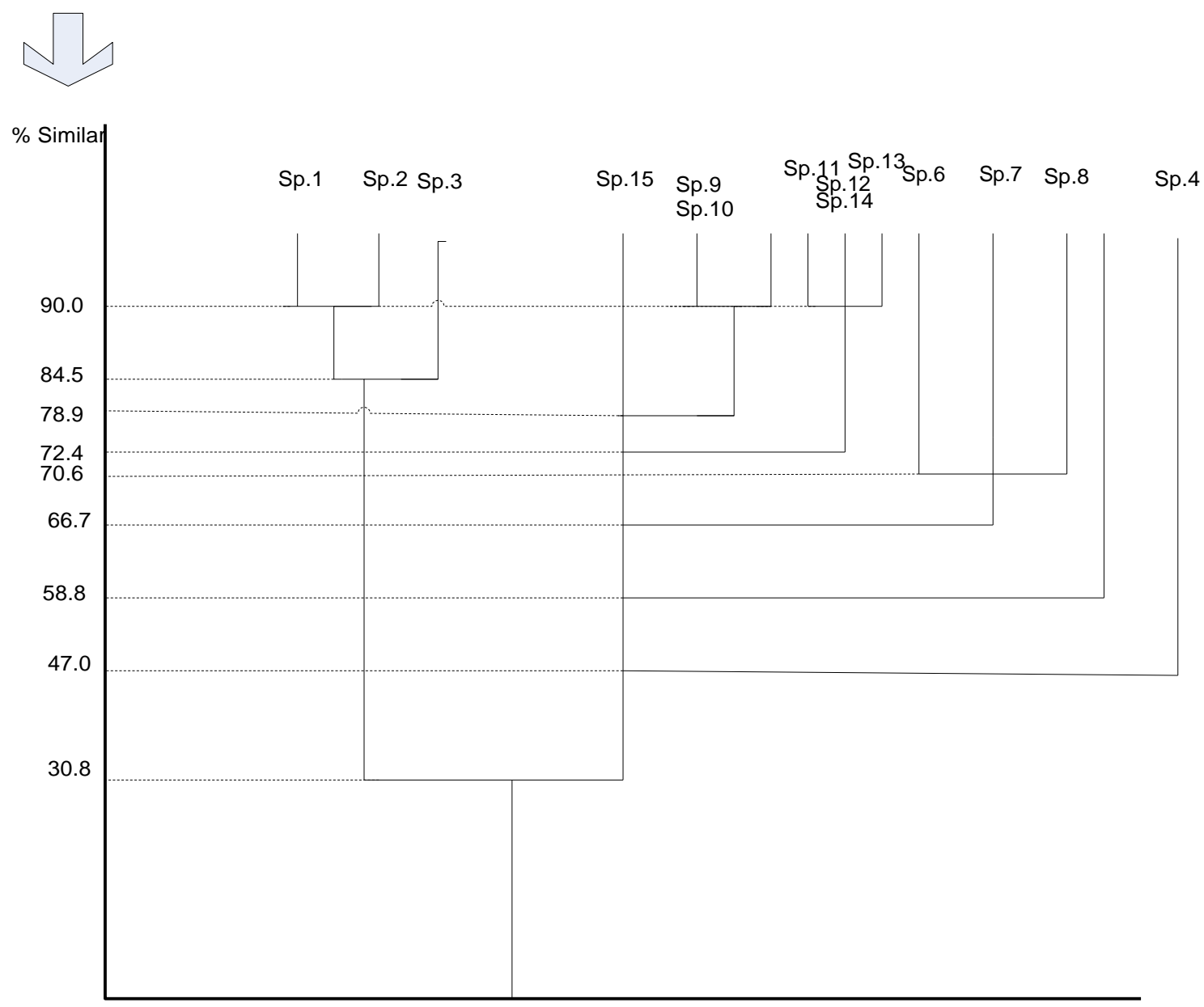

Figure 2. Dendogram of fifteen species in Jumog Waterfall. Sp. 1 - Sp. 15 are species number 115, It is referred to Table 1.

Bryophyte consists of three divisions, Kumar, 2010). Form of sporogonium of they are Liverwort (Hepaticae), Hornwort anthocerotae, which is like horn, is used to (Anthocerotae), and Mosses classify in to new order. Then, molecularly, (Bryophytae/Musci). This classification has Bryophyte also divided on three Classis been developed. Recently, there are two systems that classify the bryophyte. Many experts divided bryophyte in three classis when another only two classis (Hepaticae and Bryophytae). The most supported (Campbell and Jane, 2008). The classification used in this research (Table 1) based on three Classes classification system.

The Results showed fifteen species of classification is three Classis of bryophyte. It was supported by Campbell $(1918,1941)$, and Yudianto, (1992) In addition, Vashishta (1976) also served similar classification of bryophyte (Vashishta, B.R., Sinha, A.K., bryophyte found in Jumog Waterfall only in the river that connected to waterfall. More species of bryophyte reported in Cemoro Sewu hiking track in Lawu Mount which found 85 species (Romawati et al., 2013). They consist of 34 families and 56 genera. In 
the Lawu Mount more species of bryophyte can be found in hiking track rather than in the riverside of Jumog Waterfall. It was because hiking track has more sampling area and bryophyte can be found in many substrate not only soil and stone, but also attached on the tree trunk or other material.

Then, 20 species of bryophyte in national park of merapi 16 months after eruption (Musyarofah et al., 2015). Sixty six species also reported in Sinabung Mount and Deleng Lancuk national park (Pasaribu, 2013). The most identified of bryophyte ever reported was 159 species in Patuha Mount, West Java, which is represent $1 / 6$ of all species in Java Island (Gradstein et al., 2011). This research founded six species of Dicranales Order and Fissidentales that consists of three species of each order. Three species are namely Dicranum japonicum, Plagiomnium ciliare, and Bartramia laevisphaera of Dicranales Order then Fissidens fontanus, Fissidens javanicus, and Fissidens nobilis of Fissidentales (Figure 3.). Fissidentales order has specific morphological characters. It has erect stem or rather slope. It has vagina, lancet leaf form, and pinnatus leaf formation. It lays on the stone, low light intensity (shady place), and high water humidity.

On the other hand, the member of order Metzgeriales, Jungermanniales, Bryales, Funariales and Anthocerotales only one species found in Jumog Waterfall they are Metzgeria pubescens, Plagiochila asplenoides, Rhodobryum ontariense, Funaria hygrometrica, and Phaeoceros laveis. It because on this research only explore in the river of that connected to the waterfall.
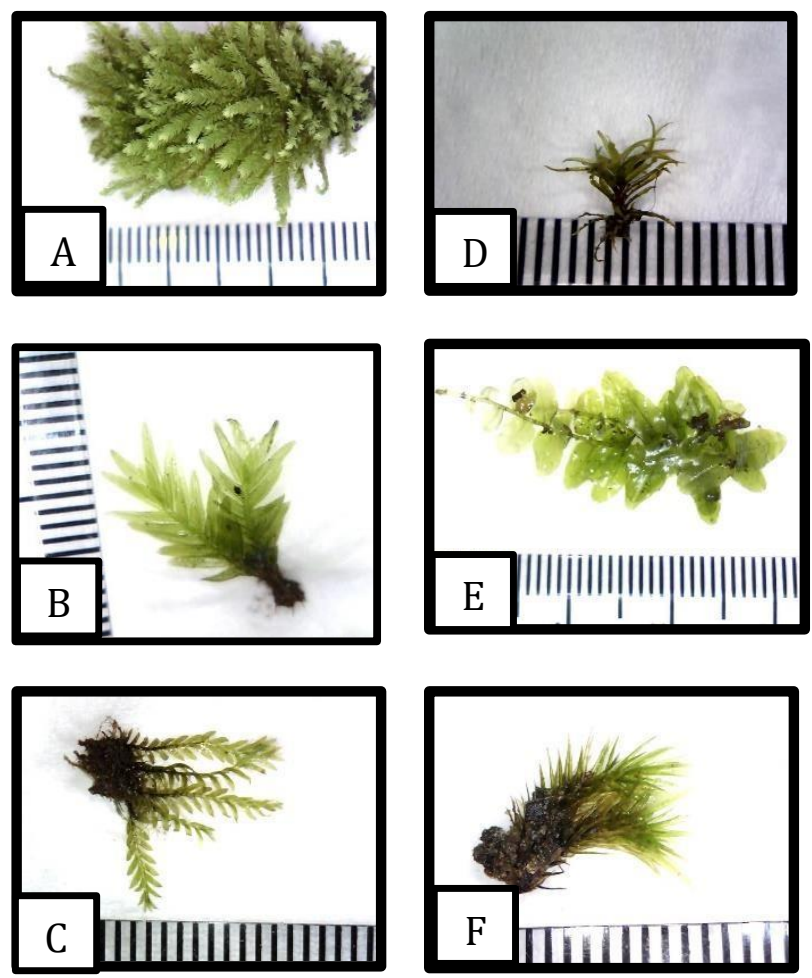

Figure 3. The most abundance species that found in Jumog Waterfall, Fissidentales Order (A, B, C) Dicranales Order (D, E, F). A. Fissidens fontanus, B. Fissidens javanicus, C. Fissidens nobilis, D. Dicranum japonicum, E. Plagiomnium ciliare, F. Bartramia laevisphaera

In Jumog waterfall also found Phaeoceros laveis with specific characters. It is member of anthocerotae and distinguished from mosses (Musci). It has horn form of sporogonium, therefore commonly it called hornwort. Figure 4 shows the characters of Phaeoceros laveis. Form of sporogonium, which looks like horn, has a role as its form of sporophyte phase (Tjitroseopomo, 2009; Yudianto, 1992). 


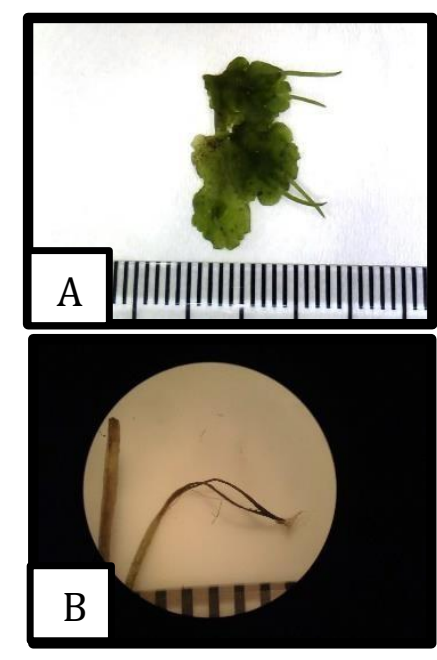

Fig

ure 4.

Charact

ers of gametophyte and sporophyte of Phaeoceros laveis. A. Gametophyte phase, B. Sporophyte phase

The exploration of bryophyte in Jumog Waterfall showed that more than fifteen species covered stone and soil. Then, they analyzed their similarity each other. Among fifteen species, there are very closely related species but another does not. Similarities among species showed in Figure 2. Dendogram served data that one species to other have similarity based on their morphological characters. Figure 2 showed that the most similar was among genus Fissidens, then among order Dicranales, Hypnobryales, and Marchantiales. They were closely related so that they grouped in the same order or genus. They are $90 \%$ similar, but in genus Fissidens, they are distinguished by their size of gametophyte and type of leaf. Order Dicranales also there is one character that distinguished them in two species. On the other hand, high similarity (90\%) also showed between Marchantia plymorpha (Order Marchantiales) and Metzgeria pubescens (Order Metzgeriales). This was caused by the size and characteristics of them were very similar than Riccia fluitans.

The most interesting feature in dendogram is low similarity (30.8\%) between species 15 (Funaria hygrometrica) and species 3(Riccia fluitans L.). This low similarity caused a branch that distinguished liverwort, hornwort, and mosses. Liverwort and hornwort were grouped in one line (Sp.1, Sp.2, Sp.3) and mosses in another line. Mosses closer to Sp.15 (Funaria hygrometrica) than to liverwort., the dendogram clarified that the hornwort is closer related to liverwort than mosses.

\section{CONCLUSION}

There were fifteen species that covered stone and soil in the riverside that connected to Jumog Waterfall. The highest similarity among species was $90 \%$. They were grouped in genus Fissidentales, Order Dicranales, and Hypnobryales. The lowest similarity was 30.8\%. They were between Funaria hygrometrica and Riccia fliutans. It distinguished liverwort, hornwort, and mosses.

\section{ACKNOWLEDGMENTS}

Thanks to Universitas Muhammadiyah Surakarta for the financial support.

\section{REFERENCES}

Anonimous (2015) Jumog Waterfall, Google earth.

Aryanti, N. S. and Gradstein, S. R. (2007) 
'Wallace's line and the distribution of the liverworts of Sulawesi', Cryptogamie Bryologie. Elsevier, 28(1), pp. 3-14.

Bawaihaty, N., Istomo and Hilwan, I. (2014) 'Keanekaragaman dan Peran Ekologi Bryophyta di Hutan Sesaot', Jurnal Silvikultur Tropika, 05(April), pp. 13-17.

Campbell, N. A. and Jane, B. (2008) 'BIOLOGI', in, p. 2008.

Dodik (2011) Air Terjun Jumog. Available at: http://www.karanganyarkab.go.id/ 20110124/air-terjun-jumog/.

Goffinet, B. and Shaw, A. J. (2009) 'Bryophyte Biology', in. New York: Cambridge University Press. Available at: http://scholar.google.com/scholar? $\mathrm{hl}=$ en\&btnG=Search\&q=intitle:Bryo phyte+Biology\#0.

Gradstein, R. et al. (2011) 'BRYOPHYTES OF MOUNT PATUHA, WEST JAVA, INDONESIA', REINWARDTIA, 13(3), pp. 1-5.

Hölscher, D. et al. (2004) 'The importance of epiphytes to total rainfall interception by a tropical montane rain forest in Costa Rica', Journal of Hydrology, 292(1-4), pp. 308-322. doi: 10.1016/j.jhydrol.2004.01.015.

Musyarofah, Akmal, H. and Ariyanti, N. S. (2015) 'KEANEKARAGAMAN LUMUT HATI DAN LUMUT TANDUK PASCA ERUPSI DI TAMAN NASIONAL GUNUNG MERAPI, YOGYAKARTA', Journal of Bogor Agricultural University, 1, pp. 16891699. doi: 10.1017/CB09781107415324.004.

Pasaribu, N. (2013) 'Studi Pendahuluan Lumut Di Lau Kawar, Kabupaten Karo', Prosiding Semirata FMIPA Universitas Lampung, 2013 Studi, pp.
193-198.

Romawati, Ariyanti, N. S. and Akmal, H. (2013) 'Keanekaragaman Lumut Di Jalur Pendakian Cemoro Sewu Gunung Lawu , Jawa Timur', Journal of Bogor Agricultural University. Available at: http://repository.ipb.ac.id/handle/ 123456789/66674?show=full.

Tjitroseopomo, G. (2009) Taksonomi tumbuhan (Schizophyta, Thallophyta,Thallophyta, Broyphyta, Pteridophyta) Prof. Yogyakarta: Gadjah Mada University Press.

Vashishta, B.R., Sinha, A.K., Kumar, a. (2010) 'Botany for Degree Students: BRYOPHYTA', in. New Delhi: S. Chand \& Company Ltd., Ram Nagar, New Delhi, pp. 7-10. Available at: http://books.google.com.pk/books/ about/Botany_for_Degree_Students. html?id=l5YCGwAACAAJ\&pgis=1.

Yudianto, S. A. (1992) Pengantar cryptogamae. Kedua. Bandung: TARSITo. 